Research Article

\title{
Factors Affecting Hypertension in the Adult Population of the Marmara Region, Turkey: A Descriptive Field Study
}

\author{
Olgun Göktaş $\mathbb{D}^{1}{ }^{1}$ Tunay Şentürk $(\mathbb{D})^{2}$ and Canan Ersoy ${ }^{3}{ }^{3}$ \\ ${ }^{1}$ Family Practice Unit, Bursa Uludağ University, Family Health Center, Bursa, Turkey \\ ${ }^{2}$ Department of Cardiology, Bursa Uludağ University, Faculty of Medicine, Bursa, Turkey \\ ${ }^{3}$ Department of Internal Medicine, Division of Endocrinology and Metabolism, Bursa Uludağ University, Faculty of Medicine, \\ Bursa, Turkey \\ Correspondence should be addressed to Olgun Göktaş; olgun_goktas@hotmail.com
}

Received 10 September 2020; Revised 7 November 2020; Accepted 15 December 2020; Published 31 December 2020

Academic Editor: Massimo Salvetti

Copyright ( 2020 Olgun Göktaş et al. This is an open access article distributed under the Creative Commons Attribution License, which permits unrestricted use, distribution, and reproduction in any medium, provided the original work is properly cited.

\begin{abstract}
Introduction. Hypertension is an increasingly prevalent global public health problem. Nutritional culture and lifestyle are among the factors related to hypertension. The aim of this study was to evaluate the prevalence and influential factors of hypertension in the adult population of the Marmara region, Turkey. Methods. The study was conducted in 10 provinces in the Marmara region between June 01, 2018, and November 30, 2018. Participants included 2353 patients over 18 years of age diagnosed with hypertension by any of the 30 family physicians working in the Family Health Centers in these provinces. After the participants provided written consent, a survey consisting of 25 questions was administered by their family physicians. SPSS 25.0 (IBM Corporation, Armonk, New York, United States) was used for all statistical analysis calculations. Results. The patients included 1449 females (61.6\%) and 904 males (38.4\%). Among the respondents, 1555 (73.1\%) had primary hypertension etiology and 572 (26.9\%) had secondary etiology. While 1614 patients (68.6\%) did not exercise at all, 739 patients (31.4\%) reported exercising; 1026 patients (43.9\%) did not restrict salt in their diet; and 1134 patients $(48.2 \%)$ had a family history of hypertension. Conclusion. Since individual and environmental factors affect the etiology of hypertension, it is recommended that family physicians address these factors first as part of a holistic approach for hypertension prevention, diagnosis, treatment, and follow-up.
\end{abstract}

\section{Introduction}

Hypertension is an increasingly common public health problem in developed and developing countries. It is also one of the most common causes of death in every region of the world $[1,2]$. The Seventh Report of the Joint National Committee on Prevention, Detection, Evaluation, and Treatment of High Blood Pressure (BP) (JNC7) described hypertension as a systolic blood pressure (SBP) $\geq 140 \mathrm{mmHg}$ and/or diastolic blood pressure (DBP) $\geq 90 \mathrm{mmHg}$ [3]. These values were also accepted as the hypertension diagnostic thresholds in many different guidelines reported after JNC7 [4-6]. Worldwide, hypertension is especially relevant to cardiovascular and renal diseases, and the prevalence of the condition is gradually increasing $[7,8]$. Several studies have examined the prevalence and factors influencing hypertension in different parts of the world [9-11], demonstrating cultural differences in the disease. There are cultural and regional differences in the rates of hypertension awareness, prevalence, affecting factors, results, and benefits.

Many national and internationally accepted guidelines from Europe and North America offer recommendations for diagnosing and treating hypertension. However, there are differences in these guidelines, and some suggestions are not consistent with clinical practice in Turkey [12] owing to the cultural differences in nutrition and lifestyle, such as the excessive use of salt. Such inconsistent guidelines can lead to increases in the prevalence of hypertension [13]. Awareness, treatment, and control of hypertension are especially important to the prevention and management of chronic kidney disease [14]. Considering the prevalence and seriousness of hypertension and the inconsistent information 
about this health problem in Turkey, we aimed to evaluate the prevalence of hypertension and its association with risk factors by conducting a survey with adults in lists registered by family physicians. The study was conducted in the provinces of Marmara, one of Turkey's most industrialized and populous regions.

\section{Materials and Methods}

2.1. Study Design. The study was carried out in 10 provinces in the Marmara region: Balıkesir, Bilecik, Bursa, Edirne, Istanbul, Kurklareli, Kocaeli, Sakarya, Tekirdağ, and Yalova. Çanakkale Province was not included in the study because the physician in this province is no longer consulted there. A survey about hypertension was completed by adult patients (18 years or older) who had been diagnosed with having hypertension with a $\mathrm{SBP} \geq 140 \mathrm{mmHg}$ and/or DBP $\geq 90 \mathrm{mmHg}$ (or already using an antihypertensive drug) by Family Health Center physicians between June 01, 2018, and November 30, 2018 in these provinces. The prevalence of hypertension in Turkey has been reported to be $31.8 \%$. Considering this value, for a total population of 66694 registered patients over the age of 18 (combined number of patients registered at all of the Family Health Centers in the region), the necessary sample size for the study was calculated as 7407, with a significance level of 0.05 and an error of $d=0.01$. After the sample size was calculated by the sizeproportional stratification method, the percentage and number of samples per family physician were determined.

Written consent was obtained from each patient who agreed to participate. The 25-item questionnaire was administered to each participant by their family physician. The doctors read the questions out loud to the patients, and the patients provided a verbal response. The doctors documented the responses digitally, along with a digital copy of the questionnaire. The answers were recorded synchronously on the online web link provided by the Vademecum medication guide company. During the study period, the questionnaire was administered to a total of 2353 people with hypertension. The participants' BP readings were taken by a standard measurement method with automatic (armworn, electronic) BP measurement devices approved by the Turkish Society of Hypertension and Renal Diseases. Patients were asked about the duration and etiology of their hypertension, the medications they had used in the treatment of hypertension, and whether the medication they were using was their first treatment or if it was a modified treatment. Newly developed antihypertensives such as Mineralocorticoid Receptor Antagonists (MRAs), Aldosterone Synthase Inhibitors (ASIs), Aminopeptidase Inhibitors, Angiotensin Receptor-Neprilysin Inhibitors, Natriuretic Peptide Receptor Agonists (NPR-A), and Vasopeptidase Inhibitors were also asked about. The survey included questions about the participants' sociodemographic characteristics, such as their age, marital status, monthly income, and highest level of education. The survey also asked them to describe their alcohol consumption as "never use," "social use," or "continuous (regular) use." They reported their smoking habits, diet, exercise status, comorbidities, hypertension risk factors, and the presence of conditions related to hypertension, such as retinopathy, nephropathy, and left ventricular hypertrophy. Those patients with organ involvement were also asked to provide retrospective glucose, urea, creatinine, glomerular filtration rate, and lipid parameters.

2.2. Statistical Analysis. SPSS 25.0 (IBM Corporation, Armonk, New York, United States) statistical software program was used in all calculations. Quantitative variables are expressed as mean \pm SD (standard deviation), median, (minimum/maximum), percentile (25/75), and percentile (5/95), as shown in Tables 1 and 2. Categorical variables are given as $n(\%)$. It is more effective to use the central trend (mean and median) and central distribution measures (SD, $\min / \max$, and percentiles) for this type of study, as it provides detailed information for the general sample and population.

\section{Results}

Analysis indicated that the prevalence of hypertension in the Marmara region was $31.8 \%$. Of the 2353 hypertensive patients who took part in the study, 1449 were women $(61.6 \%)$ and 904 were men (38.4\%). Among the respondents, 1555 (73.1\%) had primary etiology and 572 (26.9) had secondary etiology. Regarding exercise, 1614 patients (68.6\%) reported not exercising at all and 739 patients (31.4\%) reported exercising regularly. Regarding diet, 1026 patients (43.9\%) had not restricted their salt intake (Table 1).

The drug most commonly used by patients in this study to treat hypertension was an angiotensin converting enzyme (ACE) inhibitor (1264 patients, 32.7\%). In contrast, only one patient was using a newly developed drug $(0.1 \%)$. In terms of risk factors, 1032 (43.9\%) of the patients were in the risky age group and $1134(48.2 \%)$ had a family history of hypertension. There were 379 patients $(16.1 \%)$ who self-reported as smokers. Diabetes mellitus was present in 692 patients (29.4\%), hyperlipidemia in 538 patients (22.9\%), retinopathy in 58 patients $(5.1 \%)$, nephropathy in 66 patients $(5.8 \%)$, and left ventricular hypertrophy in 51 patients (4.5\%) (Table 2).

\section{Discussion}

In 2003, the PatenT study, a nationwide field survey of 4910 people, was conducted to determine the prevalence of hypertension in Turkey (PatenT: Prevalence, awareness, and treatment of hypertension in Turkey). The study results indicated the prevalence to be $31.8 \%$ of the adult population [15].

Our study was a similar cross-sectional field scan, and we found the prevalence of hypertension in the Marmara region to be $31.8 \%$. Although this rate is considered high, it does indicate that hypertension prevalence has not increased since 2003 . The practice of family medicine, which began in the last 10 years in Turkey, and the role of family physicians may have contributed to keeping the rate from increasing. Their success in curbing increasing rates of hypertension to the point where the rate has stabilized speaks to the effectiveness of the individual protection, diagnosis, treatment 
TABLE 1: Sociodemographic features, body measures, and duration of hypertension of the study participants.

\begin{tabular}{|c|c|c|c|c|c|c|}
\hline & & & $n$ & & & $\%$ \\
\hline \multicolumn{7}{|l|}{ Province } \\
\hline & Balıkesir & \multicolumn{3}{|c|}{32} & \multicolumn{2}{|c|}{1.4} \\
\hline & Bilecik & \multicolumn{3}{|c|}{24} & \multicolumn{2}{|c|}{1.0} \\
\hline & Bursa & \multicolumn{3}{|c|}{670} & \multicolumn{2}{|c|}{$\begin{array}{c}1.0 \\
28.5\end{array}$} \\
\hline & Edirne & \multicolumn{3}{|c|}{17} & \multicolumn{2}{|c|}{0.7} \\
\hline & İstanbul & \multicolumn{3}{|c|}{813} & \multicolumn{2}{|c|}{34.6} \\
\hline & Kirklareli & \multicolumn{3}{|c|}{27} & \multicolumn{2}{|c|}{1.1} \\
\hline & Kocaeli & \multicolumn{3}{|c|}{508} & \multicolumn{2}{|c|}{21.6} \\
\hline & Sakarya & \multicolumn{3}{|c|}{68} & \multicolumn{2}{|c|}{2.9} \\
\hline & Tekirdağ & & 149 & & & .3 \\
\hline & Yalova & & 45 & & & 9 \\
\hline Gender & & & & & & \\
\hline & Female & & 1.449 & & & 1.6 \\
\hline & Male & & 904 & & & 3.4 \\
\hline Marital status & & & & & & \\
\hline & Single & & 493 & & & 1.0 \\
\hline & Married & & 1.860 & & & 9.0 \\
\hline Level of education & & & & & & \\
\hline & Primary school or below & & 1.238 & & & 2.6 \\
\hline & Secondary school & & 503 & & & 1.4 \\
\hline & High school & & 309 & & & 3.1 \\
\hline & University & & 303 & & & 2.9 \\
\hline Monthly income & & & & & & \\
\hline & Over $10,000 \mathrm{TL}$ & & 43 & & & .8 \\
\hline & $5,000 \mathrm{TL}$ to $10,000 \mathrm{TL}$ & & 221 & & & .4 \\
\hline & Minimum wage or below & & 1.074 & & & 5.6 \\
\hline & Minimum wage $\mathrm{x} 2$ & & 500 & & & 1.2 \\
\hline & Minimum wage $\mathrm{x} 2$ to $5,000 \mathrm{TL}$ & & 515 & & & 1.9 \\
\hline Diet (daily salt intake) & & & & & & \\
\hline & 1 teaspoon & & 576 & & & 4.6 \\
\hline & 1 dessert spoon & & 563 & & & 4.1 \\
\hline & 1 tablespoon & & 173 & & & .4 \\
\hline & No & & 1.026 & & & 3.9 \\
\hline Alcohol use & & & & & & \\
\hline & Does not use & & 2.141 & & & 1.0 \\
\hline & Social drinker & & 178 & & & .6 \\
\hline & Continuous use & & 34 & & & .4 \\
\hline Smoking & & & & & & \\
\hline & Quit & & 407 & & & 7.3 \\
\hline & Uses & & 331 & & & 4.1 \\
\hline & Does not use & & 1.615 & & & 8.6 \\
\hline Etiology & & & & & & \\
\hline & Primary & & 1.555 & & & 3.1 \\
\hline & Secondary & & 572 & & & 5.9 \\
\hline Exercise & & & & & & \\
\hline & Yes & & 1.614 & & & 3.6 \\
\hline & No & & 739 & & & 1.4 \\
\hline & $n$ & Mean \pm SD & Median & $(\operatorname{Min} / \max )$ & P. $(25 / 75)$ & P. (5/95) \\
\hline Height $(\mathrm{cm})$ & 2.305 & $163.00 \pm 9.34$ & 162.00 & $(140 / 205)$ & $(156 / 170)$ & $(15 / 179)$ \\
\hline Weight (kg) & 2.305 & $80.05 \pm 14.90$ & 79.00 & $(40 / 138)$ & $(70 / 89)$ & $(58 / 107)$ \\
\hline $\operatorname{BMI}\left(\mathrm{kg} / \mathrm{m}^{2}\right)$ & 2.305 & $30.16 \pm 5.31$ & 29.65 & $(15.57 / 55.26)$ & $(26.51 / 33.2)$ & $(22.53 / 39.67)$ \\
\hline Waist $(\mathrm{cm})$ & 2.303 & $100.71 \pm 33.17$ & 100.00 & $(10 / 1138)$ & $(91 / 109)$ & $(79 / 121)$ \\
\hline Hip $(\mathrm{cm})$ & 2.303 & 112.78 & 108.00 & $(50 / 8893)$ & $(101 / 116)$ & $(92 / 130)$ \\
\hline Duration of HT(months) & 2.353 & $15.94 \pm 15.53$ & 11.00 & $(1 / 49)$ & $(5 / 21)$ & $(1 / 49)$ \\
\hline
\end{tabular}

P.: percentile, min: minimum, max: maximum, SD: standard deviation. BMI: body mass index; duration of HT: duration of hypertension. 
TABLE 2: Medications used, risk factors, organ involvement, and laboratory findings for patients with hypertension.

\begin{tabular}{|c|c|c|c|c|c|c|}
\hline & & & $n$ & & & $\%$ \\
\hline \multicolumn{7}{|c|}{ If taking medication; diuretic } \\
\hline & No & & 1.238 & & & 67.3 \\
\hline & Yes & & 602 & & & 32.7 \\
\hline \multicolumn{7}{|c|}{ If taking medication; adrenergic antagonist } \\
\hline & No & & 1.459 & & & 79.3 \\
\hline & Yes & & 381 & & & 20.7 \\
\hline \multicolumn{7}{|c|}{ If taking medication; renin-angiotensin system etkileyen ilaç } \\
\hline & No & & 576 & & & 31.3 \\
\hline & Yes & & 1.264 & & & 68.7 \\
\hline \multicolumn{7}{|c|}{ If taking medication; vascular smooth muscle } \\
\hline & No & & 1.318 & & & 71.6 \\
\hline & Yes & & 522 & & & 28.4 \\
\hline \multicolumn{7}{|c|}{ If taking medication; new drug being developed } \\
\hline & No & & 1.839 & & & 99.9 \\
\hline & Yes & & 1 & & & 0.1 \\
\hline \multicolumn{7}{|c|}{ Risk factors; age (male 45 and female over 65) } \\
\hline & No & & 1.321 & & & 56.1 \\
\hline & Yes & & 1.032 & & & 43.9 \\
\hline \multicolumn{7}{|c|}{ Risk factors; family history } \\
\hline & No & & 1.219 & & & 51.8 \\
\hline & Yes & & 1.134 & & & 48.2 \\
\hline \multicolumn{7}{|l|}{ Risk factors; smoking } \\
\hline & No & & 1.974 & & & 83.9 \\
\hline & Yes & & 379 & & & 16.1 \\
\hline \multicolumn{7}{|c|}{ Risk factors; diabetes mellitus } \\
\hline & No & & 1.661 & & & 70.6 \\
\hline & Yes & & 692 & & & 29.4 \\
\hline \multicolumn{7}{|c|}{ Risk factors; hyperlipidemia } \\
\hline & No & & 1.815 & & & 77.1 \\
\hline & Yes & & 538 & & & 22.9 \\
\hline \multicolumn{7}{|c|}{ Organ involvement; retinopathy } \\
\hline & No & & 1.076 & & & 94.9 \\
\hline & Yes & & 58 & & & 5.1 \\
\hline \multicolumn{7}{|c|}{ Organ involvement; nephropathy } \\
\hline & No & & 1.068 & & & 94.2 \\
\hline & Yes & & 66 & & & 5.8 \\
\hline \multicolumn{7}{|c|}{ Organ involvement; left ventricular hypertrophy } \\
\hline & No & & 1.083 & & & 95.5 \\
\hline & Yes & & 51 & & & 4.5 \\
\hline \multicolumn{7}{|l|}{ Organ involvement; no } \\
\hline & No & & 772 & & & 68.1 \\
\hline & Yes & & 362 & & & 31.9 \\
\hline \multicolumn{7}{|c|}{ Organ involvement; unknown } \\
\hline & No & & 510 & & & 45.0 \\
\hline & Yes & & 624 & & & 55.0 \\
\hline & $n$ & Mean \pm SD & Median & $(\operatorname{Min} / \max )$ & P. $(25 / 75)$ & P. $(5 / 95)$ \\
\hline Triglyceride $(\mathrm{mg} / \mathrm{dL})$ & 1.868 & $157.67 \pm 98.51$ & 138.00 & $(1 / 1651)$ & $(101 / 188)$ & $(64 / 310)$ \\
\hline Total chol (mg/dL) & 1.883 & $210.59 \pm 48.82$ & 208.00 & $(12 / 800)$ & $(179 / 239)$ & $(137 / 290)$ \\
\hline HDL chol (mg/dL) & 1.860 & $51.47 \pm 15.07$ & 49.00 & $(4 / 173)$ & $(42 / 58)$ & $(32 / 80)$ \\
\hline LDL chol (mg/dL) & 1.800 & $130.54 \pm 39.68$ & 128.50 & $(12 / 326)$ & $(104.5 / 152)$ & $(69.5 / 199)$ \\
\hline Glucose $(\mathrm{mg} / \mathrm{dL})$ & 1.928 & $114.72 \pm 39.17$ & 103.00 & $(11 / 440)$ & $(93 / 120)$ & $(82 / 190)$ \\
\hline Urea $(\mathrm{mg} / \mathrm{dL})$ & 2.097 & $38.17 \pm 28.61$ & 31.00 & $(2.14 / 335.98)$ & $(23 / 43)$ & $(10 / 92.02)$ \\
\hline Creatinine $(\mathrm{mg} / \mathrm{dL})$ & 1.925 & $1.17 \pm 04.26$ & 0.81 & $(0.14 / 85)$ & $(0.69 / 0.97)$ & $(0.55 / 1.4)$ \\
\hline GFR $(\mathrm{ml} / \mathrm{dk})$ & 1.670 & $91.61 \pm 38.61$ & 90.80 & $(0.28 / 275.7)$ & $(69 / 110.67)$ & $(30.663 / 159.48)$ \\
\hline
\end{tabular}


regulation, and strict follow-ups provided by the family physicians.

Another recent study reported the overall prevalence of hypertension as $32.96 \%$ [16]. In adults in the United States, the prevalence of hypertension was found to be $34.2 \%$ when using conventional threshold values of BP and $44.0 \%$ when using the newer recommendations (defining BP as elevated at $120-129 /<80 \mathrm{mmHg}$ and stage 1 hypertension at $130-139$ and/or $80-89 \mathrm{mmHg}$ ) [17]. In the etiology of hypertension, primary or essential hypertension caused by environmental or genetic causes accounts for $90-95 \%$ of adult cases, while secondary hypertension caused by vascular, endocrine, and other causes constitute $2-10 \%$ of cases [18]. In our study, 1555 (73.1\%) patients had primary etiology, and 572 (26.9\%) had secondary etiology. This rate of secondary hypertension is much higher than the average $2-10 \%$ of cases. Therefore, further studies are needed to investigate the underlying conditions and determine the cause of the high secondary hypertension rate in Turkey. The fact that the Marmara region is the most industrialized and densely populated region of Turkey may be a factor related to the prevalence rates for hypertension among the patients in this study.

The majority of the participants with hypertension in this study did not exercise at all, and nearly half of them (43.9\%) did not restrict their dietary intake of salt. These results emphasize the need for family physicians to apply a holistic approach to treating their patients who have hypertension. Physicians must work with these patients to increase their awareness of their condition and encourage them to make simple yet life-saving lifestyle changes to improve their health and reduce hypertension.

There are several different types or groups of antihypertensive medications that can effectively reduce $\mathrm{BP}$. The Joint National Committee (JNC6) and (JNC7) recommend diuretics and beta blockers as the first choice in the treatment of uncomplicated hypertension $[19,20]$. The drug most commonly prescribed to patients in our study is the one that affects the renin-angiotensin system. In contrast, the least used medication among the patients is from the newly developed drug group. One study reported that the most preferred drug group in the treatment of hypertension is an ACE inhibitor [21]. However, according to a study conducted in Brazil, the five most commonly used drugs were hydrochlorothiazide (a diuretic), losartan (an angiotensin receptor blocker), captopril (an ACE inhibitor), enalapril (an ACE inhibitor), and atenolol (a beta blocker), in descending order [22]. These results show that treatments may differ, as lifestyle factors, environmental factors, ethnicity, and the genetic composition of populations of different countries contribute to determining the most appropriate and most commonly used drugs for treating hypertension.

A study in China showed that five risk factors-increased age, male gender, city center work, cardiopulmonary insufficiency, and being overweight-were related to a higher prevalence of hypertension [23]. In our study, family history, age, diabetes mellitus, hyperlipidemia, and smoking were risk factors that were positively related to developing hypertension. In another study, metabolic syndrome, diabetes mellitus, and obesity were shown to be the conditions most commonly related to the development of hypertension [24]. These differing findings support the notion that cultural and environmental factors influence the prevalence of the condition.

A 2017 retrospective cohort study reported the incidence rate of target organ damage in hypertensive patients as $40.3 \%$. The most common target organ damage was heart failure $(11.6 \%)$, followed by ischemic heart disease (8.3\%). The least common types of target organ damage were retinopathy $(0.9 \%)$, atrial fibrillation $(0.9 \%)$, and sexual dysfunction (0.67\%) [25]. While $50 \%$ of patients with hypertension in our study did not know if they had organ involvement, $39.1 \%$ stated definitively that they did not. Others reported known related organ damage: $5.8 \%$ of the patients had nephropathy, 5.1\% retinopathy, and $4.5 \%$ had left ventricular hypertrophy. These results show the need for awareness of organ involvement in patients with hypertension.

A study conducted in Canada reported that $67 \%$ of hypertension cases treated by family physicians in a 10 -year period were well controlled through the physicians' care. The authors of the study suggest that a family physician may be the best suited clinician for detecting, evaluating, managing, and controlling hypertension. They also suggest that the family physician can be duly supported in providing care with help from secondary- and tertiary-care counselors, laymen, and the Ministry of Health in that country [26]. Similarly, based on the results of our study, we would like to emphasize that a coordinated approach involving family physicians and secondary and tertiary clinicians may be the most effective in the context of preventive medicine, diagnosis, treatment, and follow-up for hypertension. Additional support should be made available from specialist associations and health authorities.

4.1. Our Limitations. We were unable to attain the required sample size, in the current study. Since our study period was limited to six months and the working physician's resources were restricted, limited data could be collected. Since the selection of samples was randomized, even if only one-third of the required samples were collected, we believe that the sample size was large enough to not seriously affect the reliability of the results. Another limitation of this study was that the patients' examined lifestyle habits did not include their regular consumption of caffeinated beverages, particularly coffee or tea. It has been suggested that the consumption of caffeine correlates to BP and blood lipid levels. Future studies should include coffee and tea consumption as potential factors affecting BP. Another limitation is that the results are based on self-report survey responses rather than clinically measured data. There is always a risk of self-reported information lacking accuracy, either because participants are not entirely truthful or they may lack knowledge about some of the information requested. Therefore, even though many of our results are consistent with those from other studies in similar populations, they may not be entirely accurate. Additionally, it was not clear in our survey if the sodium intake reported by the patients 
refers only to the quantity they add to their food in cooking or at the table or if it represents their actual total sodium intake, including sodium naturally occurring in foods or added by manufacturers as a seasoning or as a preservative. Future studies addressing these issues may further clarify the relationship between these factors and the effective treatment of hypertension.

\section{Conclusions}

Our study results show that the prevalence of hypertension in Turkey's Marmara region is high, and, similar to the country in general, hypertension in Marmara is affected by different factors. However, although Marmara is the most crowded and industrialized region of the country, the prevalence of hypertension in that region is not higher than that for the country nationwide, suggesting that family medicine, put into practice in recent years in Turkey, has been successfully established. Individuals are benefitting from being closely monitored and cared for by their family physicians. Health policies that support family medicine and other clinicians should be developed to promote awareness of hypertension, its risk factors, and the severe complications that may arise. Further support for family medicine practitioners may positively affect public health.

\section{Data Availability}

The data used to support the findings of this study are available from the corresponding author upon request.

\section{Ethical Approval}

The study was performed after receiving the approval of the Clinical Ethics Committee of Bursa Uludağ University (reference number: 2018-8/17, dated: 24.04.2018) and in accordance with the Declaration of Helsinki. In addition to the ethical approval, a written letter of permission (reference number. 49654233-604.02 dated: 20.07.2018) from The Republic of Turkey Ministry of Health, Ankara, was obtained.

\section{Conflicts of Interest}

The authors report no conflicts of interest.

\section{Acknowledgments}

The authors would like to thank Editage Vademecum (http://www.vademecumonline.com.tr) for its online support, (http://www.editage.com) for English language editing, ARGEV (The Turkish Family Medicine Research Development and Education Foundation http://www.argev.org.tr) for providing education before the study, and their colleagues for their cooperation and all the family physicians who have contributed to this study by participating in the province of the Marmara Region, Turkey. The authors thank Taner Yiğit Balıkesir Bandırma Number 14 Family Health Center, Murat Yaşa Özdemir Balıkesir Sındırgı Şehit Erol Olçak Family Health Center, Nevzat Çağlayan Bilecik Merkez Merkez Family Health Center, Tülay Gündüzcü Bursa Nilüfer Beşevler Family Health Center, Mehtap
Yılmaz Bursa Osmangazi Çirişhane Family Health Center, Bilgen Küçük Bursa Osmangazi Küplüpınar Family Health Center, Murat Girginer Bursa Yıldırım Ertuğrulgazi Family Health Center, Nilüfer Nilgün Yiğitalp Bursa Yıldırım Ortabağlar Family Health Center, Mustafa Akay Edirne Merkez Gazimihal Family Health Center, Emine Sezgi Aslaner İstanbul Bağcılar Sancaktepe Family Health Center, Rahmi Muvaffak İstanbul Bahçelievler Nazife Yemen Family Health Center, Reha Gökalp İstanbul Beşiktaş Levent Family Health Center, Tamer Altay İstanbul Beşiktaş Levent Family Health Center, Esra Noyan İstanbul Eyüp Göktürk Family Health Center, Şule Coşkun Güven İstanbul Maltepe Number 20 Family Health Center, Zerrin Timur İstanbul Maltepe Number 1 Family Health Center, Elvan Gökalp İstanbul Pendik Güllübağlar Family Health Center, Madina Turakulava İşel İstanbul Pendik Esenyalı Family Health Center, Senem Aslan İstanbul Pendik Esenyalı Family Health Center, Onur Faysal Dağ İstanbul Zeytinburnu Number 3 Family Health Center, Hasan Onat Kurklareli Merkez A. Mehmet Genç Family Health Center, Ayça Adile Boyac1 Kocaeli İzmit Alikahya Family Health Center, Ülker Şenyuva Mola Kocaeli İzmit Kolordu Family Health Center, Banu Hopanc1 Kocaeli Kandira Merkez Family Health Center, Funda Düven Kocaeli Kartepe Köseköy İstasyon Family Health Center, Erdinç Atış Sakarya Adapazaı Cumhuriyet Family Health Center, İsmail Yavuz Tekirdağ Çorlu Havuzlar Family Health Center, Selamet Gündoğdu Tekirdağ Çorlu Yenibağlar Family Health Center, Erdinç Yılmaz Yalova Merkez Gazi Family Health Center, and Ünal Atılgan Yalova Merkez Süleymanbey Family Health Center.

\section{References}

[1] P. M. Kearney, M. Whelton, K. Reynolds, P. K. Whelton, and J. He, "Worldwide prevalence of hypertension," Journal of Hypertension, vol. 22, no. 1, pp. 11-19, 2004.

[2] C. J. Murray and A. D. Lopez, "Mortality by cause for eight regions of the world: global burden of disease study," The Lancet, vol. 349, no. 9061, pp. 1269-1276, 1997.

[3] A. V. Chobanian, G. L Bakris, H. R. Black et al., "The seventh report of the Joint national committee on prevention, detection, evaluation, and treatment of high blood pressure," JAMA, vol. 289, no. 19, pp. 2560-2572, 2003.

[4] G. Mancia, R. Fagard, K. Narkiewicz et al., "2013 ESH/ESC guidelines for the management of arterial hypertension: the task force for the management of arterial hypertension of the European Society of Hypertension (ESH) and of the European Society of Cardiology (ESC)," European Heart Journal, vol. 34, no. 28, pp. 2159-2219, 2013.

[5] B. Williams, G. Mancia, W. Spiering, E. A. Rosei, and M. Azizi, "ESC scientific document group. 2018 ESC/ESH guidelines for the management of arterial hypertension," European Heart Journal, vol. 39, no. 33, pp. 3021-3104, 2018.

[6] P. K. Whelton, R. M. Carey, W. S. Aronow, D. E. Casey, and K. J. Collins, "2017 ACC/AHA/AAPA/ABC/ACPM/AGS/ $\mathrm{APhA} / \mathrm{ASH} / \mathrm{ASPC} / \mathrm{NMA} / \mathrm{PCNA}$ guideline for the prevention, detection, evaluation, and management of high blood pressure in adults: executive summary: a report of the American College of Cardiology/American Heart Association task force on clinical practice guidelines," Journal of the American College of Cardiology, vol. 71, no. 19, pp. 2199-2269, 2018. 
[7] J. He and P. K. Whelton, "Epidemiology and prevention of hypertension," The Medical Clinics of North America, vol. 81, no. 5, pp. 1077-1097, 1997.

[8] P. K. Whelton, "Epidemiology of hypertension," The Lancet, vol. 344, pp. 101-106, 1994.

[9] H. Ueshima, X. H. Zhang, and S. R. Choudhury, "Epidemiology of hypertension in China and Japan," Journal of Human Hypertension, vol. 14, no. 10-11, pp. 765-769, 2000.

[10] R. Gupta, "Hypertension in India: definition, prevalence and evaluation," Journal of the Indian Medical Association, vol. 97, no. 3, pp. 74-80, 1999.

[11] K. Wolf-Maier, R. S. Cooper, J. R. Banegas et al., "Hypertension prevalence and blood pressure levels in 6 European countries, Canada, and the United States," JAMA, vol. 289, no. 18, pp. 2363-2369, 2003.

[12] M. Arıcı, A. Birdane, K. Güler et al., "Türk hipertansiyon uzlaşı raporu (Turkish hypertension consensus report)," Türk Kardiyol Dern Arş - Arch Turk So Cardiol (Archives of the Turkish Society of Cardiology), vol. 43, no. 4, pp. 402-409, 2015.

[13] Y. Erdem, M. Arici, B. Altun et al., "The relationship between hypertension and salt intake in Turkish population: SALTÜRK study," Blood Pressure, vol. 19, no. 5, pp. 313-318, 2010.

[14] B. Altun, G. Süleymanlar, C. Utaş et al., "Prevalence, awareness, treatment and control of hypertension in adults with chronic kidney disease in Turkey: results from CREDIT study," Kidney \& Blood Pressure Research, vol. 36, no. 1, pp. 36-46, 2012.

[15] B. Altun, M. Arici, G. Nergizoğlu et al., "Prevalence, awareness, treatment and control of hypertension in Turkey (the PatenT study) in 2003," Journal of Hypertension, vol. 23, no. 10, pp. 1817-1823, 2005.

[16] S. Singh, R. Shankar, and G. P. Singh, "Prevalence and associated risk factors of hypertension: a cross sectional study in Urban Varanasi," International Journal of Hypertension, vol. 2017, Article ID 5491838, 10 pages, 2017.

[17] J. A. Lamprea-Montealegre, L. R. Zelnick, Y. N. Hall, N. Bansal, and I. H. de Boer, "Prevalence of hypertension and cardiovascular risk according to blood pressure thresholds used for diagnosis," Hypertension, vol. 72, no. 3, pp. 602-609, 2018.

[18] M. R. Alexander, C. Editor, and E. H. Yang, "What are the causes and prevalence of primary and secondary hypertension (high blood pressure)?" 2019, https://emedicine.medscape. com/article/241381.

[19] Joint National Committee, "The sixth report of the joint national committee on prevention, detection, evaluation, and treatment of high blood pressure," Archives of Internal Medicine, vol. 157, no. 21, pp. 2413-2446, 1997.

[20] A. V. Chobanian, G. L. Bakris, H. R. Black et al., "And the national high blood pressure education program coordinating committee, "the seventh report of the Joint national committee on prevention, detection, evaluation, and treatment of high blood pressure (the JNC 7)," Hypertension, vol. 42, no. 6, pp. 1206-1252, 2003.

[21] Q. Gu, R. Paulose-Ram, C. Dillon, and V. Burt, "Antihypertensive medication use among US adults with hypertension," Circulation, vol. 113, no. 2, pp. 213-221, 2006.

[22] S. S. Mengue, A. D. Bertoldi, L. R. Ramos et al., "Access to and use of high blood pressure medications in Brazil," Revista de Saude Publica, vol. 50, no. 2, p. 8, 2016.

[23] X. Liu, Z. Xiang, X. Shi et al., "The risk factors of high blood pressure among young adults in the Tujia-Nationality
Settlement of China," BioMed Research International, vol. 2017, Article ID 8315603, 6 pages, 2017.

[24] G. de Simone, R. B. Devereux, M. Chinali et al., "Risk factors for arterial hypertension in adults with initial optimal blood pressure: the Strong Heart Study," Hypertension, vol. 47, no. 2, pp. 162-167, 2006.

[25] T. M. Abegaz, Y. G. Tefera, and T. B. Abebe, "Target organ damage and the long term effect of nonadherence to clinical practice guidelines in patients with hypertension: a retrospective cohort study," International Journal of Hypertension, vol. 2017, Article ID 2637051, 8 pages, 2017.

[26] K. V. Rudnick, D. L. Sackett, S. Hirst, and C. Holmes, "Hypertension: the family physician's role," Canadian Family Physician, vol. 24, pp. 477-484, 1978. 